\title{
DUNAI SZEZON
}

\section{Időszakos közösségi terek a Duna-parton}

A folyópart jellegzetes közterülethasználati zónái és a szezonális használat új lehetőségei Ábra: saját szerkesztés
Budapest vonzerejét az idelátogatók számára páratlan városképe, világörökségi területei, historikus belvárosa jelenti. És persze a Duna. Tanulságos a turisták szemével látni a partot, akik a Szabadság híd összekötőelemein naplementét nézve borozgatnak, és a rakpart életveszélyes forgalmán keresztül is leküzdik magukat a vízhez. A város ma robbanásszerü turisztikai növekedést él meg, ez gazdasági előnyei mellett feszítő konfliktusként jelenik meg, különösen a közterületeken, így a parton is. A belvárosi Duna-part közvetlen használatát azonban mind az alsó rakpartok forgalma, mind a vízparti látványt elfoglaló szálloda- és rendezvényhajók sora ellehe-

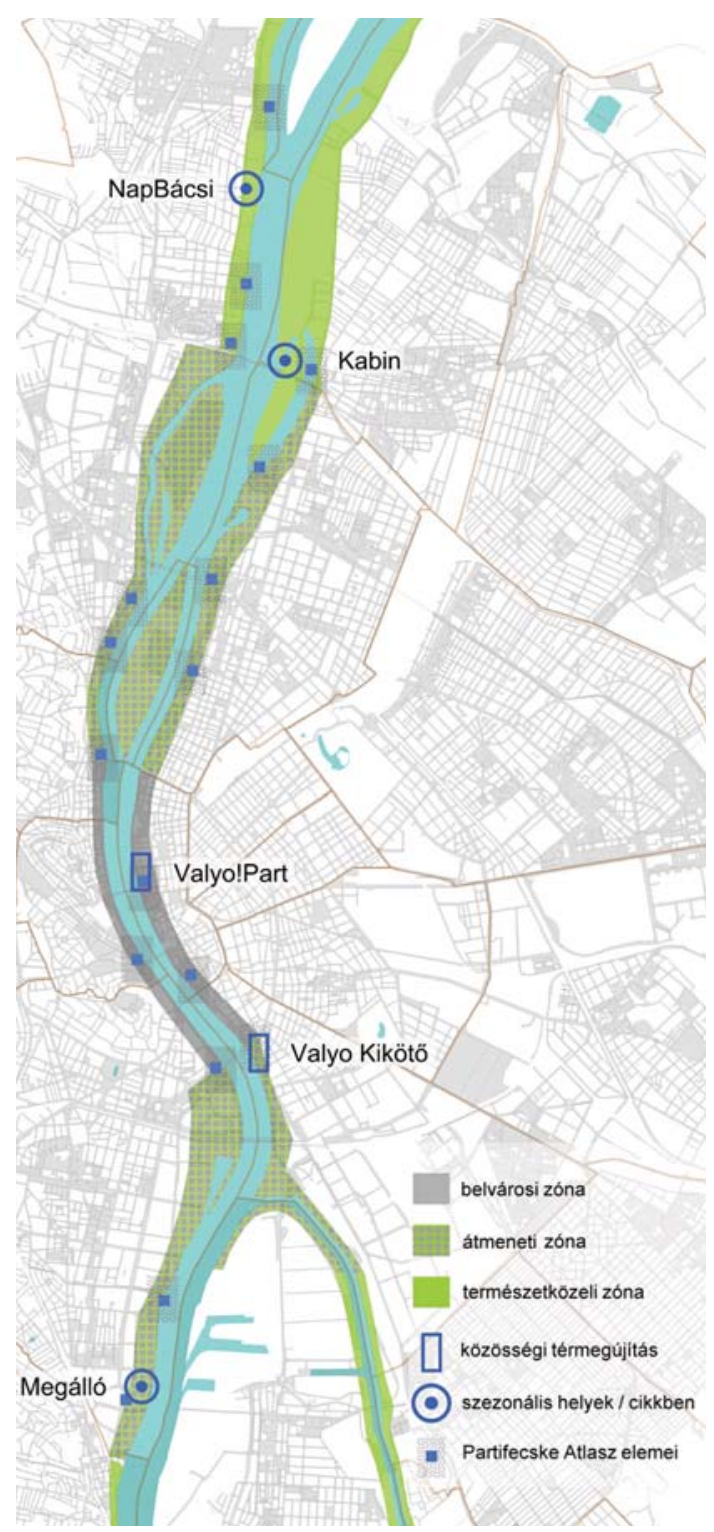

tetleníti, a városlakók többségének mentális térképéről szinte hiányzik a folyó. Jó hely, amit mégsem használunk. Egyszerre van túlhasználat a belvárosban és elfeledettség azon kívül.

Az elmúlt években megjelentek olyan alulról jövő, közösségi kezdeményezések, melyek időszakosan, de birtokba vették a Duna-partot, igényként a szezonális vendéglátás trendjét is átalakították, és a túltelített, hozzáférhetetlen belvárosi partok helyett a külső helyszíneken, a Rómain, a Népszigeten vagy a déli részeken kerestek helyet. Az időszakos közterület-használat mind imázsformáló, mind közösségi célú, használatbővítő szerepében fontos része a városképnek, a kapcsolódó területek gazdasági prosperitását támogatva turisztikai célokat is szolgál a városlakók megelégedettségén túl. [1] A kisebb léptékű Duna-parti közösségi fejlesztéseknek rövid és középtávon ugyan elsősorban lokális jelentőségük van, azonban a turisták egyre nagyobb hányada mutat érdeklődést az egyedi, helyiek által kedvelt, a városnézésen túlmutató látnivalók iránt, hiszen az ide érkező turisták közel fele a 25-44 éves korosztályba esik. [2] A külső területek felélesztése emiatt lehetőség a turizmus koncentrációjának oldására is, eszközként hatékonyan tolva ki a belvárosi Duna-használat - forgalom miatt nehezen megvalósítható - igényét a külső városrészek felé.

A cikk a szezonális használat építészeti megjelenését járja körül, bemutatva az ideiglenes építészet arculati rendszerként való kezelését, néhány, az elmúlt években Budapesten megépült példát és a közösség szerepét egyegy parti terület fejlesztésében.

\section{Partifecskék atlasza}

A Duna-parti idényszerü használat arculatának kialakítására készült el a főváros megbízásából 2016-ban a Partifecske atlasz, a Zsuffa és Kalmár Építész Müterem munkájaként. A kiadvány a Duna-part örökségi látványába minőségében illeszkedő pavilonok flexibilisen alakítható, moduláris elemrendszerét mutatja be, mely rendszer állandó és változó elemekkel is számol. A megoldás egyszerre racionális, tiszta: rendszerben látjuk, mi, hol és hogyan alkalmazható, ugyanakkor érzékeny, ahogy a környezethez illesztve jelenik meg az infrastruktúrát és a finom tömegeket is csatlakoztató mozaikos szőnyeg. 

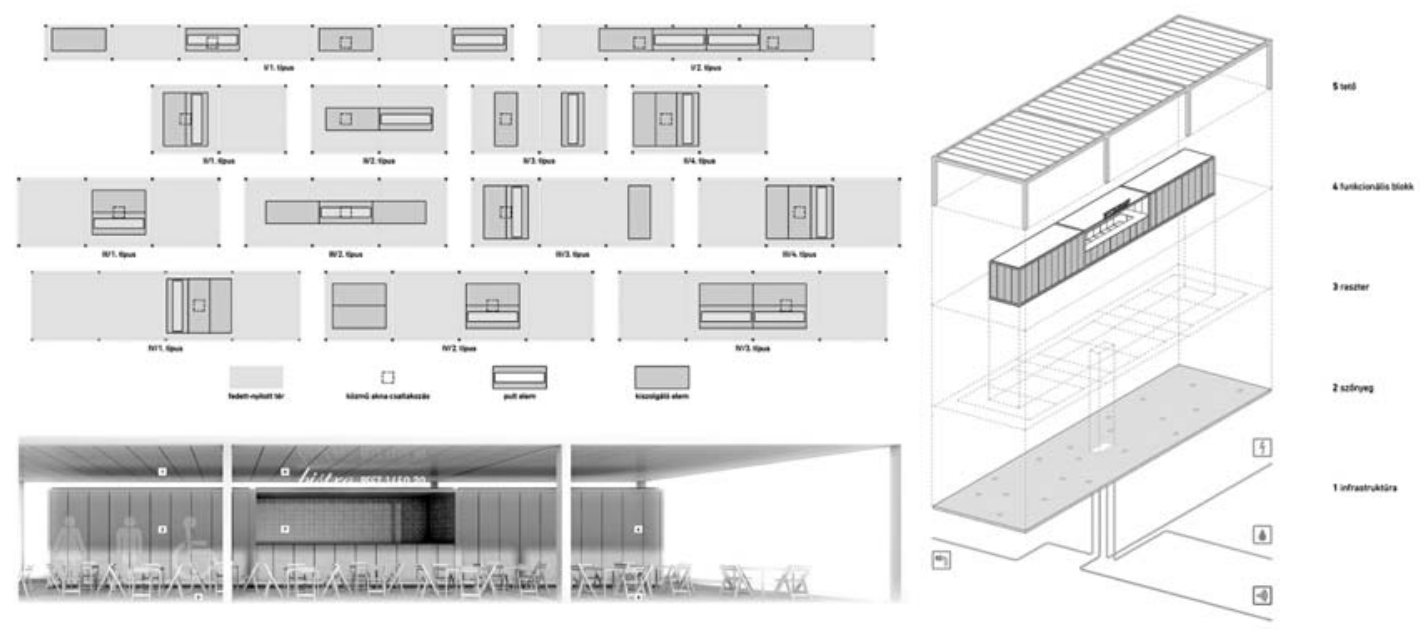

Partifecske-pavilonok flexibilisen alakítható, moduláris elemrendszere

Ábra: Partifecske atlasz

A pavilonok elhelyezését és az ahhoz kapcsolódó attitűdöt háromféle helyzetben vizsgálták, amelyekre mintaterveket is készítettek: a) belvárosi környezetben illeszkedés, b) kiemelt területen szigorú szabályozás, c) külső területeken kísérletezés. Az elhelyezés a meglévő városi helyzetek belakását állítja előtérbe, így hasznosulhatnak olyan különleges helyzetek is, mint a hidak alatti terek. A kézikönyv a közterületek átmeneti hasznosításának lehetőségei mellett a szükséges vizuális rendrakás témaköreit is körüljárja. A kritikus látványelemzést követően a part menti sáv és a kikötői úszóművek környezetének megtisztítására is tesz javaslatot. A kötetnek kettős célja volt: a jelenleg alulhasznosított területek időszakos használatának előkészítése (támogatás), illetve a túlhasznált területek épített elemeire vonatkozó szabályozási környezet megteremtése (ellenőrzés), mely később Budapest településképi arculati kézikönyvének (2017) Dunaparti fejezeteibe [3] épült bele.

\section{Vízállásjelentés és kabinok}

A kísérletező attitűdre a külső területeken találunk izgalmas, megépült példákat. Közös bennük, hogy az ideiglenesség esztétikája állandó és időszakos elemek finom egyensúlyában jelenik meg, szellemesen reagálva a vízszintek és az idő változásaira.

A Napbácsi olyan hely, ami mintha mindig is ott lett volna, pedig a Római-parton itt építmény csak tavasztól őszig helyezhető el. Ezért is lett épület helyett jármú, így a Napbácsinak van műszaki vizsgája, rendszáma és féklámpája is. [4] Egy folyónak napról napra változik a vízszintje, idénybeli használata, áradások idején a folyó menti táj radikálisan átalakul. Erre reagál a hely alapkoncepciója, ahol nemcsak a bár tud árvíz esetén arrébb gurulni, de a partot használó nyugágyak és keréken guruló talicskaasztalok is a változó vízálláshoz igazíthatók. A természetes partból, vízállásból kibontott terv a spontán használatra épít, a tervezők, Kalmár László, Krona-
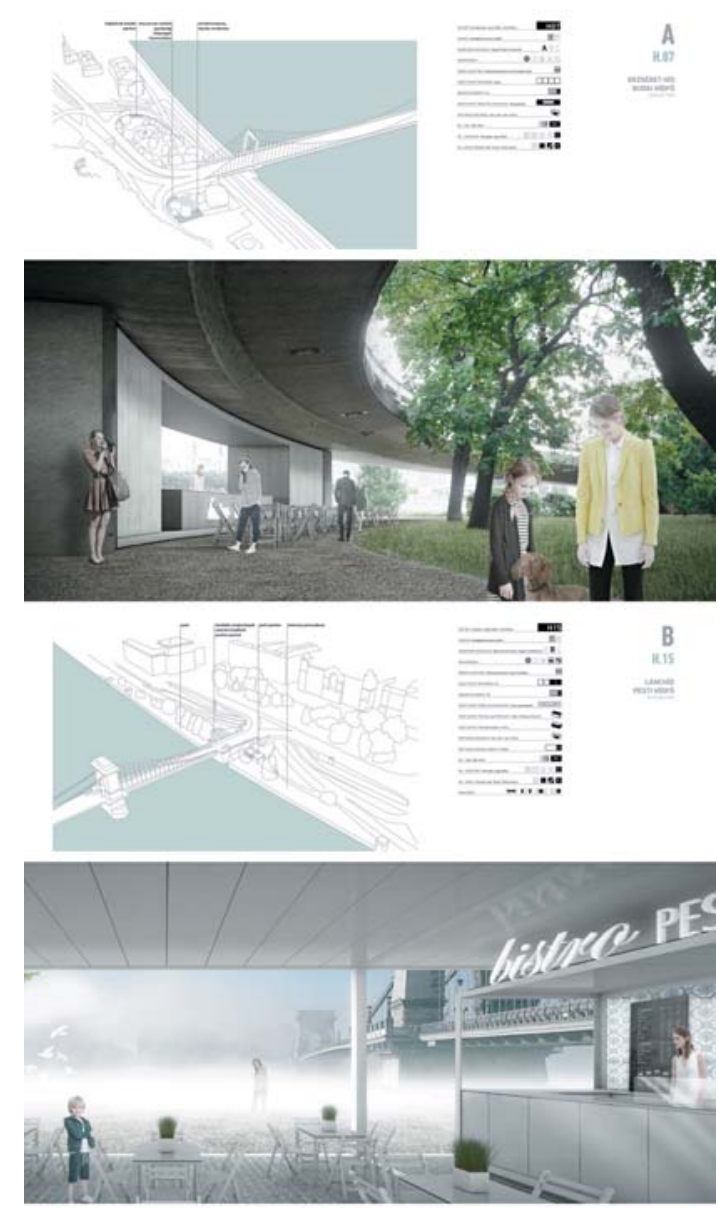

Pavilonok terve háromféle helyzetre: a) illeszkedés: Erzsébet hídnál; b) szigorú szabályozás: Lánchídnál; c) kísérletezés: Tímár utcánál Ábra: Partifecske atlasz

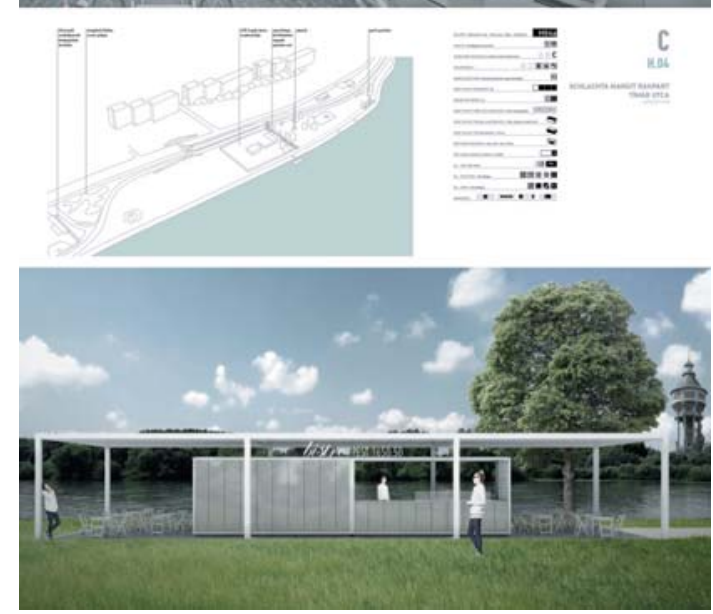




\section{Irodalom / References}

[1] Michalkó, Gábor: Boldogító utazás, MTA Földrajztudományi Kutatóintézet, Budapest 2010, p 66.

[2] KSH: A Magyarországra tett külföldi utazások száma, hozzáférhető:

$<$ http://www.ksh.hu/docs/hun/xstadat/xstadat_eves/i_ogt006.html> [utolsó belépés: 2019-04-30].

[3] Budapest településképi arculati kézikönyve, Fővárosi Közgyűlés 1319/2017 (IX 29) határozatával elfogadva, pp 159-179.

[4] Kalmár, László: „Napbácsi”, Metszet, Vol 8, No 1 (2017), pp 8-11.

[5] Hory, Gergely: „Tértermelés a Duna fölött - A Szabadság híd alternatív használatának téri vizsgálata", Metszet, Vol 10, No 3 (2019), pp 38-41, DOI:10.33268/Met.2019.3.7 [6] Oswalt, Philipp - Overmeyer, Klaus Misselwitz, Philipp: Urban Catalyst - The Power of Temporary Use, DOM Publishers, Berlin 2013, p 32.

[7] Wood, Hannah: Spatial Activism: Profiling a New Wave of European Architecture Collectives and Their Spatial Manifestos 2017, hozzáférhető: <https://archinect.com/features/article/149989510/spatial-activism-profiling-anew-wave-of-european-architecture-collectives-and-their-spatial-manifestos> [utolsó belépés: 2019-04-30].

[8] Lydon, Mike - Garcia, Anthony: A Tactical Urbanism How-To in: Tactical Urbanism: Short-term Action for Long-term Change, DOI <10.5822/978-1-61091-567-0_5>.

\section{A Napbácsi egy jármü}

Fotó: Napbácsi

A kabinok szabadon használhatók, a parton közösségi teret hoznak létre

Fotó: Szőcs Edgár

A terület hullámtérben van, a kabinok helyzetükkel követik a vízszint ingadozását, a fontosabb elemek pedig áradás esetén elvihetők Fotó: Horpáczi Dávid, checkinblog
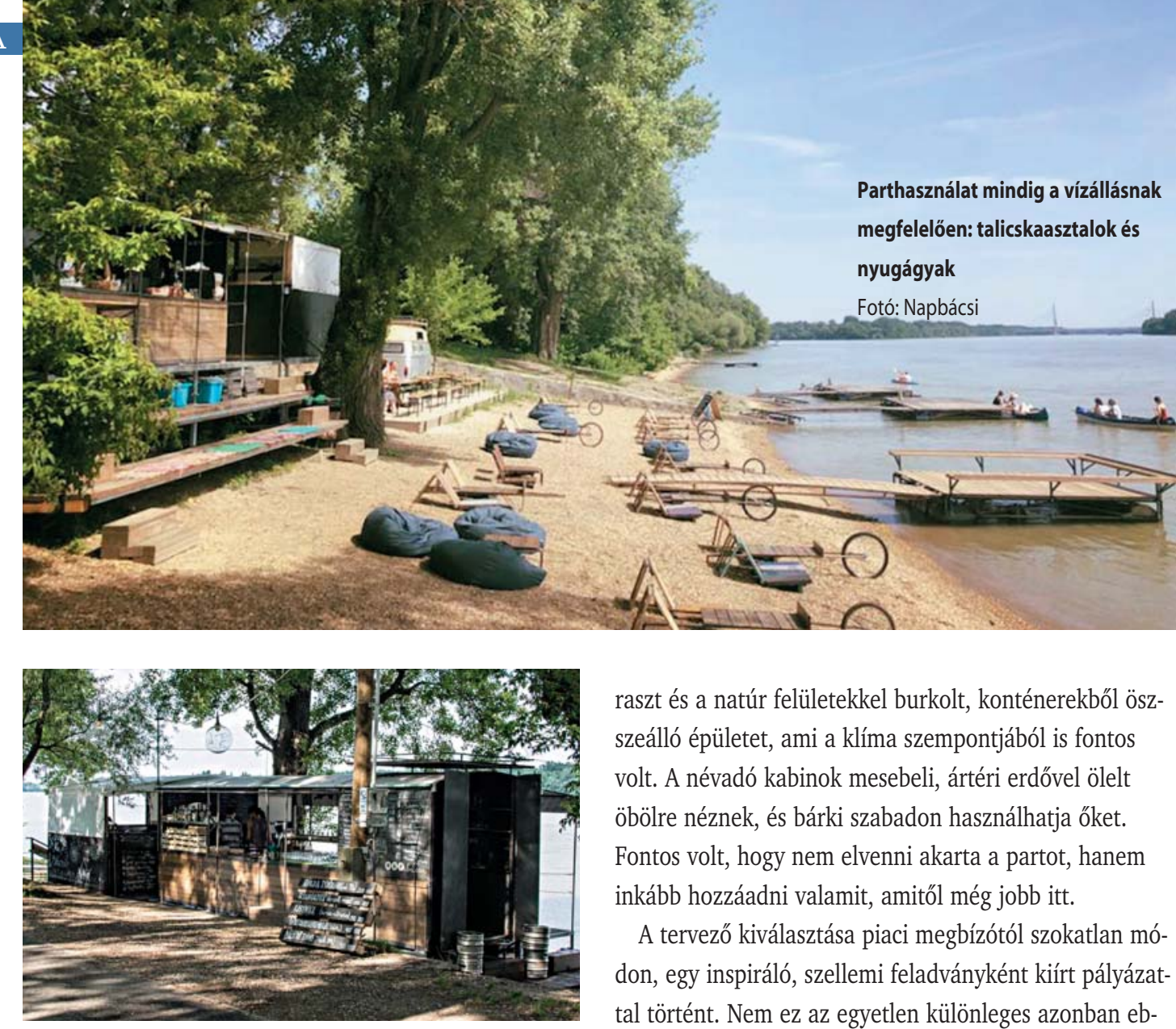

vetter Péter, Kukucska Gergő, Mihály Eszter és Pelle Zita közös munkáját éppen ennek modellezése jelentette, nemcsak a papírtérben, de a kivitelezés során is.

A Népsziget időtlen, titkos világ, ahol az ipari múlt és a vízi sport jól megfér együtt. Az elhagyatottnak tűnő hely csak pár perc sétára van a metrótól. A parton első fecske volt az Északi vasúti összekötő híd lábánál 2017. ben megtelepedő Kabin, mely nemcsak újhullámos vendéglátást, hanem különleges arculatot is hozott. Töös Dániel formatervezőként jóval szabadabban kezdhetett a tervezéshez, múvészként kereste az inspirációt a helyben. A hajógyári múlt mellett a hely ipari hangulatát a vasúti híd traverzei és a hídépítő hajódaruja, konténerei is erősítették. A Kabin kialakításában ez a kettősség tükröződik: a szárazföld felől rejtetten, míg a Duna felé, a Római irányába jól láthatóan, legyezőszerűen felnyíló látvánnyal várja az érkezőket. A szürke-vörös-bézs vitorlák a növényzettel együtt szinte teljesen befedik a te- raszt és a natúr felületekkel burkolt, konténerekből öszszeálló épületet, ami a klíma szempontjából is fontos volt. A névadó kabinok mesebeli, ártéri erdővel ölelt öbölre néznek, és bárki szabadon használhatja őket. Fontos volt, hogy nem elvenni akarta a partot, hanem inkább hozzáadni valamit, amitől még jobb itt.

A tervező kiválasztása piaci megbízótól szokatlan módon, egy inspiráló, szellemi feladványként kiírt pályázattal történt. Nem ez az egyetlen különleges azonban ebben a történetben, hiszen a tervező később a Kabin egyik üzletvezetője is lett, így lehetőséget kapva arra, hogy múködésében kísérje és az újabb igények megjelenésével folyamatosan fejlessze a projektet. Kivételes helyzet, hogy dizájnerként nemcsak a hely vizuális, de akusztikai és kulturális arculatát is kézben tarthatja, így mindig egy lépéssel előrébb jár az azóta megjelent követők előtt. Kulturális programokat, koncerteket szerveznek ide, nem csoda, hogy a Kabin a DunaPest fesztivál egyik fontos helyszíne volt.

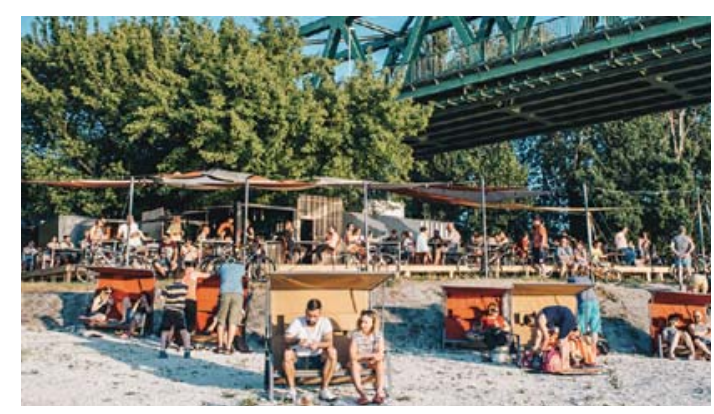

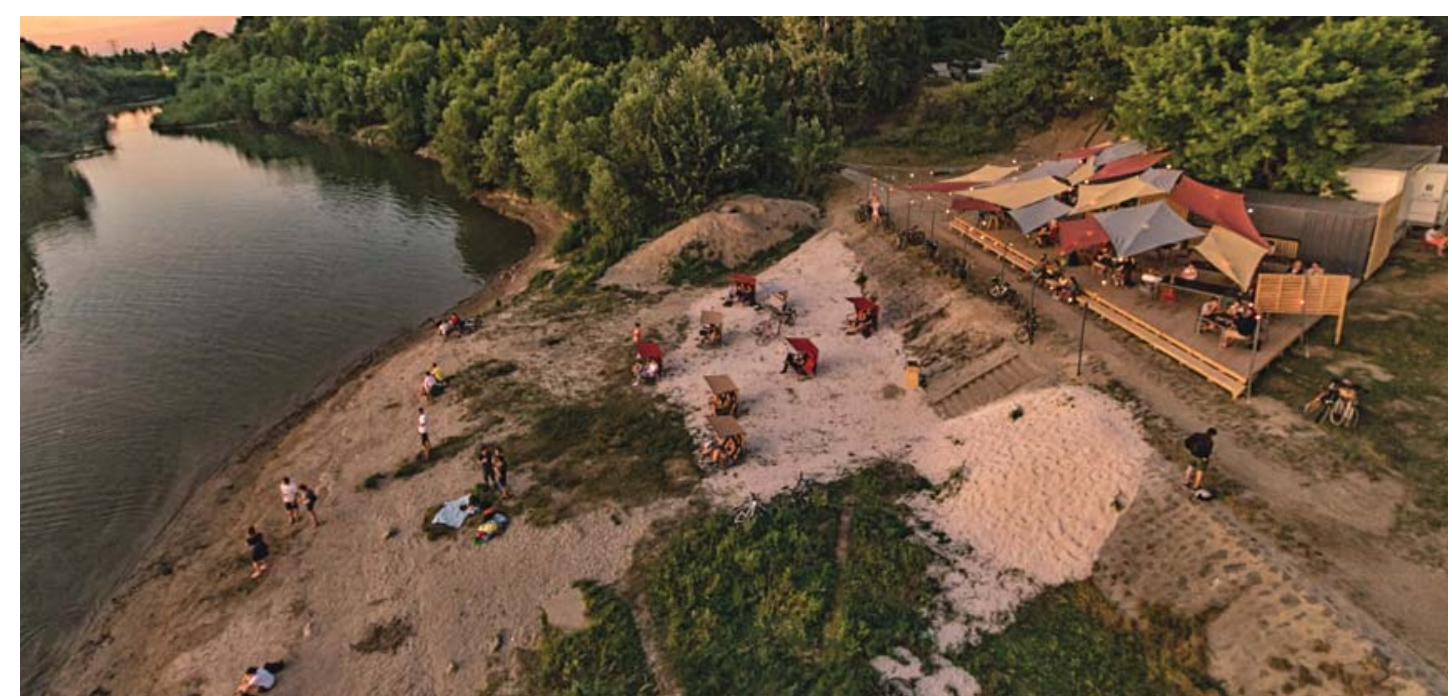




\section{Dunai partközösség}

Míg a Partifecske atlasz egységes arculatú elemekből felépülő rendszerben gondolkodik, addig a 2010 óta a Duna-partok felértékelésén dolgozó Valyo a lokálisan kialakuló elemekből épített hálózat mellett tesz hitet, ahol alulhasznosított területeket alacsony költségvetésú, kísérleti megoldásokkal, a művészet és a közösségfejlesztés eszközeivel keltenek életre és helyeznek fel a városlakók mentális térképére. A Duna belvárosi szakaszán 2011-ben a Duna-tanösvény kialakításával kezdődött meg egy három évig tartó közösségi térmegújítási folyamat, a Valyo!Part, a Lánchíd pesti hídfőjének akkor még kihasználatlan északi felén. 2015-ben sajnos már nem kaptak engedélyt az időközben felértékelődött közterület használatára, amely azóta már piaci hasznosításban állandósult.

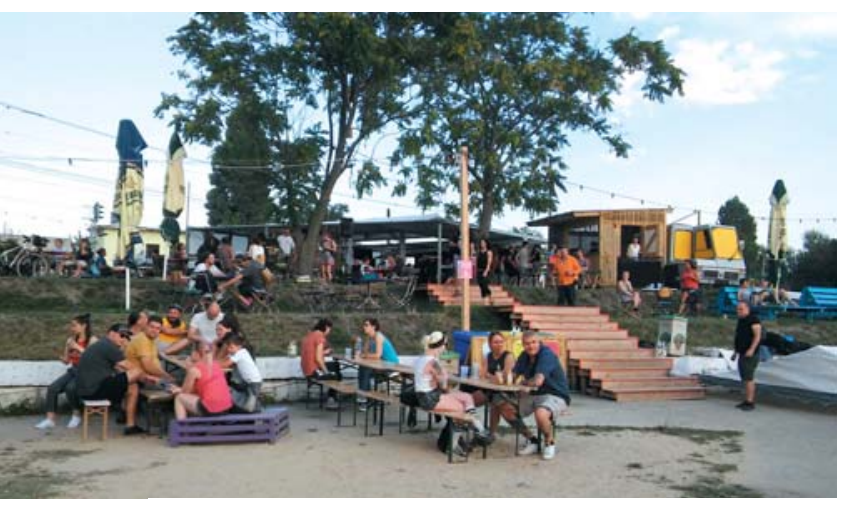

Közösségi tér közös munkával: önkéntesek építették a Valyo Kikötőt

Fotó: Fonyódi Mariann

A szervezők készek voltak más dunai helyszíneket is feléleszteni. A védjegyükké vált jármüjükben télen mobil szaunát, nyáron mozit rendeztek be, irodalmi túrára indultak a Fiatal Írók Szövetségével a Duna mentén, köztéralakítási projektjükben pedig együttműködtek más tervezőkkel is, például a Kifolyó készítésekor a Beton workshoppal. A csoport számára a Szabihíd projekt nemzetközi ismertséget [5] és nagyszámú önkéntes segítségét hozta, akikre szükség is volt 2018-ban a Valyo Kikötő, az egyesülethez köthető újabb partszakasz létrehozásában. A terület használatához a kezelőtől az engedély megszerzése három évi munkába került. A heti rendszerességgel összeülő tervező- és programszervező csapat gyakran a helyszínen, stílusosan a partra állított szaunában dolgozott, itt találták ki a főbb elemek, a színpad, a konyha, a bár kialakítását és helyét, a minimális, helyszínre szabott, egyszerűen, saját eszközökkel, aktivisták segítségével kivitelezhető infrastruktúrát. A közösségi városhasználat újabb kísérleti projektje sajnos csak egy évig tarthatott, azonban megmutatta az igényt a Duna közelségében mindenki számára nyitott térre, ahol az elhanyagolt, ipari környezet is vonzó helyszínné alakulhat közösségek bevonásával.

\section{Időszakosság és városfejlesztés}

Az átmeneti használat stratégiái a megtalált helyeken a kortárs városi kultúra rendkívül sikeres, befogadó és innovatív részévé válhatnak. [6] Létrehozóit egyszerre jellemzi a társadalmi elkötelezettség és környezetalakító szerep, olyan fiatal kreatívok, építészek és dizájnerek, akik a tervezői pozícióból új feladatkörben a közösség részeként lépnek fel. [7]

Az időszakos használat és a közösségi kezdeményezések bevonása az alulhasznosított területek, különösen a Duna-part kevésbé frekventált területeinek megújításába fontos lehetőség lehet a főváros számára: a Duna-part élettel való megtöltésében, a megszokottól eltérő prog-

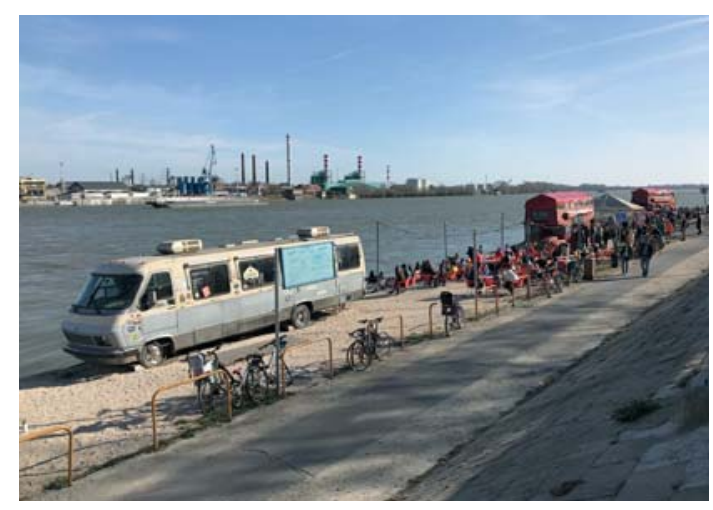

Ipari panoráma és buszok a Megállóban

Fotó: Fonyódi Mariann

ramok, tárgyak, helyszínek kialakításában, a közösségformálásban és a dunai arculat alakításában. A városvezetés számára pedig egy tervezett projekt társadalmi elfogadottságát is erősítheti, ahogy például Párizsban a Szajna-part gyalogos átalakításának sikerét is időszakos használatok sora elózte meg (Promenade des Berges de la Seine, 2013, tervezők: Franklin Azzi és Jean Christophe Choblet). Az önszerveződő csoportokon keresztül közvetlenebb kommunikáció lehetséges az egyéni városhasználókkal, ez lehetőséget teremthet a jelentős városmegújítási projektek előzetes tesztelésére, finomhangolására, bevonva a lakosságot is a tervezésbe. Ezek a tactical urbanism eszköztárát [8] is felvonultató kezdeményezések, civil aktivitások nemcsak frissességet hozhatnak egy város életébe, de az elindult folyamatok tesztelhetik a város tűrőképességét is, mennyire tolerálja a Duna-part ilyen átalakulását.

\section{Fonyódi Mariann}

PARTIFECSKE ATLASZ

Tervezők: Zsuffa és Kalmár

Építész Műterem / Kalmár László,

Kronavetter Péter, Zsuffa Zsolt

Tervezés: 2016

Megbízó: Budapest Főváros

Főpolgármesteri Hivatal,

Városépítési Főosztály

\section{NAPBÁCSI}

Tervezők: Kalmár László, Kronavetter Péter, Kukucska

Gergő, Mihály Eszter, Pelle Zita

Tervezés: 2013-2014

Kivitelezés éve: 2014

Megbízó: Napbácsi

Kivitelező: saját kivitelezés

\section{KABIN}

Tervező: Töős Dániel formatervező, a Kabin egyik üzletvezetője Tervezés: ötletpályázat 2016, tervezés 2017

Kivitelezés éve: 2017

Megbízó: Kabinpart Kft.

Kivitelező: Töős Dániel, saját

kivitelezés

Lakatosmunkák:

Marada Mihály, lakatos

\section{VALYO KIKÖTŐ}

Tervező: Kornai-Varga Dávid, Nagy Péter építészek, Valyo

Statikus: Balázs Géza

Tervezés: 2017

Kivitelezés éve: 2018

Kivitelezés: Holánszky Réka,

Kornai-Varga Dávid, Lakatos Ábel, Tömör Miklós, Dicle Sarman, továbbá rengeteg önkéntes; önkéntes koordinátor: Lohász Cili

Programszervezés: Péter

Benjamin, Szőke Tímea, Szőllőssy

Balázs, Vidra Péter

Hulladékgazdálkodás és visszaváltható pohár: Zöldövezet 


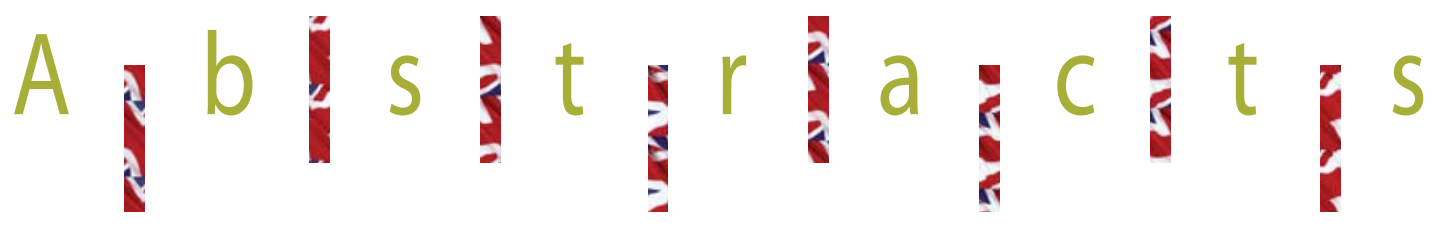

BENKŐ, Melinda - SZABÓ, Árpád: A DANUBE HISTORY IN BUDAPEST

\section{Citation: Metszet, Vol 10, № 3 (2019), pp 10-17, DOl:10.33268/Met.2019.3.1}

FUTURE AWARENESS IN THE DEVELOPMENT OF GRAPHISOFT PARK, ÓBUDA, HUNGARY

Graphisoft Park in Budapest is a spinoff project implemented by the software development compa ny that created the world leading architectural design software, ArchiCAD ${ }^{\circledR}$. The article summarises the step-by-step development process of the business park and the related university campus situated on the site of a former Gasworks. The transformation of the industrial zone on the Danube demonstrates a unique example of private real estate development implemented during the last decades. Originally the park was oriented towards the river, later its development continued at areas further away from the water and by now it communicates intensively with the adjoining urban context. Its buildings and landscaped spaces present high quality contemporary Hungarian architecture. Its atmosphere is deeply rooted in the built and natural heritage of the site. Focusing on urban design, the paper reveals the future awareness of the story of the Graphisoft Park started in 1996.

\section{PERÉNYI, Flóra - VÖRÖS, Tamás: MODERATE MATCHING}

Citation: Metszet, Vol 10, № 3 (2019), pp 18-21, DOl:10.33268/Met.2019.3.2

VIADONAU ADMINISTRATION BUILDING, ASCHACH, AUSTRIA

ARCHITECTS: DIETRICH UNTERTRIFALLER

The new Viadonau office building floats on the Danube shore as an extension to the longitudinal centre of Aschach. The, linear, one-storey house fits naturally into the existing ensemble on the banks of the Danube and follows the established morphology - yet it can redefine the environment and give it a new identity with its lightweight timber facade design. The modest and wellproportioned spatial design together with a high level of craftsmanship results an exemplary architectural solution.

\section{BABOS, Annamária: HOME BY BOAT}

Citation: Metszet, Vol 10, № 3 (2019), pp 22-25, DOl:10.33268/Met.2019.3.3
APARTMENT BUILDINGS ON THE DANUBE

\section{ARCHITECT: JOSEF HOHENSINN (HOHENSINN ARCHITEKTUR)}

How to make contact between the water and inhabitants? The development of Winter Harbour is a good example of developments on the bank of river. The idea of the design and the approach of urban development are easily recognisable: between the Danube and the existing office buildings, four large sculptural buildings are positioned. Their sculptural design creates an easily recognisable identity for this area. The buildings stand upon a site which is differentiated in appearance according to function, much like a game board, the "shipboard" includes garage spaces and public functions. Public and semi-public spaces are created, by the use of arcades, and the site is fragmented by ramps and green areas. These landscaping tools, the shaping of facades and the general planning concept enhance the quality of the development for both the inhabitants and the office workers alike, establishing various links to the Danube.

\section{FENES, Tamás - NÉMETH, Ádám: WITHOUT THE NEED FOR CONTINUITY}

\section{Citation: Metszet, Vol 10, № 3 (2019), pp 26-29, DOl:10.33268/Met.2019.3.4}

\section{ZUCKERMANDEL DISTRICT DEVELOPMENT, BRATISLAVA, SLOVAKIA}

ARCHITECTS: BOUDA MASÁR

Since the millennium, a number of new large-scale developments have sprung up along the waterfront areas of Bratislava, resulting in the rapid transformation of the cityscape. The last of these projects, the Zuckermandel mixed use development was built on the site of a historical suburb demolished during the post-war period, in a prominent location between the Castle Hill and the Danube. The article reviews the project and reaches the conclusion that although the process of reintegrating unused areas into the urban fabric is a positive trend, the Zuckermandel development represents a missed opportunity to recreate a genuine urban neighbourhood in the centre of the city.

\section{SZABÓ, Árpád - KLANICZAY, János: ON THE BORDER OF CITY AND NATURE}

\section{Citation: Metszet, Vol 10, No 3 (2019), pp 30-33, DOl:10.33268/Met.2019.3.5}

\section{ARKABARKA HOSTEL, BELGRADE, SERBIA}

ARCHITECTS: AKRITIDOU, GRBIC and PANANASTASIOU

The city of Belgrade has a strong connection to the rivers Sava and Danube and unlike most cities developed in the socialist period its riversides have been reserved for pedestrian and recreational use. Since the 1960's spontaneous bottom-up constructions started to appear, floating structures on the rivers, next to the historically symbolic Friendship park. These informal and unregulated buildings did not disrupt nature, nor did they occupy valuable land, so they were allowed to exist, gradually creating the tourist attraction that today defines the riverbanks of the city. Among the floating houses are a number of hostels, out of which the most interesting architectural piece is
Arkabara. The building has been constantly developed since its foundation in 2006, always adapting to the needs of the visitors, creating a new tourist and recreational opportunity between the urban and the natural landscape.

\section{FONYÓDI, Mariann: DANUBE SEASON}

\section{Citation: Metszet, Vol 10, № 3 (2019), pp 34-37, DOl:10.33268/Met.2019.3.6}

TEMPORARY COMMUNITY SPACES ON THE DANUBE

Temporary, interim uses and elements are important parts of the riverbank's social image and use pattern. The article discusses how these types of development may occur, showing three examples of how they can adapt to changes found along the river and throughout the seasons, and what role individual architects can play in creating community spaces. Civil activities can not only bring freshness to the life of a city, but the processes can test the tolerance of the city regarding transformation of the Danube as an urban space.

\section{HORY, Gergely: MAKING SPACE ABOVE THE DANUBE} Citation: Metszet, Vol 10, № 3 (2019), pp 38-41, DOl:10.33268/Met.2019.3.7

SPATIAL ANALYSIS OF ALTERNATIVE USES ON LIBERTY BRIDGE, BUDAPEST, HUNGARY In recent years alternative community uses have appeared on the Liberty Bridge both spontaneously and in pre-planned form. The article investigates this phenomenon from its spatial aspect and demonstrates the various stages of urban development encountered during informal events and organised programmes that create a space with that has a unique identity.

\section{BALLA, Regina: LIFE IN THE NEIGHBOURHOOD}

\section{Citation: Metszet, Vol 10, № 3 (2019), pp 42-45, DOl:10.33268/Met.2019.3.8} RESIDENTIAL DEVELOPMENTS ON THE DANUBE

The presence of natural waterways can play an important role in the regeneration of prefabricated housing estates. The water is one of the most important elements in urban design that can have a positive effect on comfort for its inhabitants. The redevelopment of the waterside can create significant new functions in respect of use and aesthetic. Due to the presence of a river these housing units are worth opening towards the Danube river as a source of liveability and practically in the neighbourhood. In Hungary more than 10 post-war neighbourhoods are located along the Danube and its branches. The potential of their positioning is increasingly being recognised as a positive factor.

\section{SZABÓ, Julianna: HIDDEN HERITAGE}

\section{Citation: Metszet, Vol 10, № 3 (2019), pp 46-49, DOl:10.33268/Met.2019.3.9}

HOLIDAY HOMES ALONG THE DANUBE

From the end of the 19th century until the Second World War, Budapest's agglomeration saw a boom in holiday villa-construction along the Danube which transformed the traditional rural nature of village development. What new values do these buildings represent? What lessons have they offered? How can we evaluate today the influences of this disappearing type of built heritage?

\section{KISSFAZEKAS, Kornélia: "IT IS THE WATER RULES"?}

\section{Citation: Metszet, Vol 10, No 3 (2019), pp 50-53, DOl:10.33268/Met.2019.3.10}

MORPHOLOGICAL CONSTANCIES AND CHANGES IN SMALL SETTLEMENTS OF THE DANUBE BEND Along an approximately $40 \mathrm{~km}$ long area between Vác and Esztergom in the Danube Bend, small settlements line up quite sparsely on both sides of the Danube. Both in the past and the present, their relationship to the riverbanks has been strongly determined by the historical settlement struc ture and the traditional mode of plot development. Due to climate change, drastic shifts of the shoreline can be expected which may significantly alter the relationship of river front settlements and the landscape space of the Danube Bend to the riverbanks. One of the biggest challenges for the local governments will be to adopt sustainable scenarios for the future and invent optimal solutions to preserve riverside settlements in spite of the dynamic processes of climate change and their inherent consequences.

\section{BALIZS, Dániel: FALSE REBUILDING}

\section{Citation: Metszet, Vol 10, № 3 (2019), pp 54-57, DOl:10.33268/Met.2019.3.11}

QUESTIONING THE URBAN REGENERATION OF VUKOVAR, CROATIA

How can we rebuild a destroyed city near the Danube in Croatia? What can a city do to regain its former inhabitants and to make them to see itself again as a liveable place with good prospects? Create new buildings and functions, use cultural tools or strengthen community participation? From Vukovar's example we can learn a lot about these issues. 